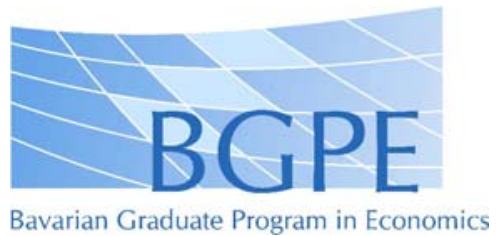

BGPE Discussion Paper

No. 20

\title{
Do the World Trade Organization and the Generalized System of Preferences foster bilateral trade?
}

\author{
Bernhard Herz \\ Marco Wagner
}

January 2007

ISSN 1863-5733

Editor: Prof. Regina T. Riphahn, Ph.D.

Friedrich-Alexander-University Erlangen-Nuremberg

(C) Bernhard Herz, Marco Wagner 


\title{
Do the World Trade Organization and the Generalized System of Preferences foster bilateral trade?
}

\author{
Bernhard Herz Marco Wagner
}

January 2007

Adresse:

Prof. Dr. Bernhard Herz

Universität Bayreuth

Lehrstuhl für Wirtschaftspolitik (VWL I)

95440 Bayreuth

Telefon: +49 - 921 - 552913

Fax: $\quad+49-921-552949$

e-mail: Bernhard.Herz@uni-bayreuth.de 


\section{Abstract \\ Do the World Trade Organization and the Generalized System of Preferences foster bilateral trade?}

World trade has grown exponentially during the last 60 years. Admittedly, it is not clear if this development can be assigned to international trade agreements like the World Trade Organization or the Generalized System of Preferences as previous empirical studies found contradicting results. In this paper we generalize the different approaches used in the literature to estimate the role of GATT/WTO and the Generalized System of Preferences for trade. We use a gravity model and apply FE estimation on a disaggregated bilateral data set of the trade flows between 145 countries across 1962-99. In our analysis we find a significant positive effect of WTO membership on bilateral trade. Referring to other multilateral institutions, we find robust evidence that membership in regional trade agreements or currency unions substantially increase bilateral trade flows as well. By contrast, we find that the Generalized System of Preferences does not foster trade in general, rather the opposite. This might be due to the opportunistic behavior of industrial countries that grant GSP schemes as long as the concerned products are relatively unimportant, but restrict them as soon as they become relevant.

JEL-Classification: C13, C15, F13, F15;

Keywords: WTO, GSP, regional trade agreements, currency union, gravity model, international trade; 


\section{Introduction}

In the period from 1960 to 2005 world trade has grown amazingly faster than world GDP. While in 2005 world output was about four times higher than in 1960 trade increased 12-fold during that time. This rapid growth in trade is related to the ongoing process of liberalization that took place under the auspices of the GATT/WTO. Since its foundation in 1947 GATT/WTO organized eight rounds of liberalization which among others reduced ad valorem tariffs on industrial products from over $40 \%$ to less than $4 \%$ on average. At the end of 2005 no less than 149 countries participated in the World Trade Organization with further countries pushing for WTO membership. It therefore comes as no surprise, that the WTO is believed to have a major impact on world trade.

Recently, this view has been challenged. Rose (2004, p. 110) estimates the influence of WTO on international trade in a gravity type approach and finds that

"membership in the WTO seems not to have an economically or statistically significant effect on trade [...]".

His results indicate that the trade patterns of WTO members are not significantly different from those of non-members. Instead, other institutional variables affect aggregated bilateral trade flows significantly, e. g. membership in a preferential trading area or in a currency union. In addition, the Generalized System of Preferences (GSP) seems to have a positive impact on bilateral trade. Under GSP schemes countries can grant reduced or zero tariff rates for selected products originating from developing countries. The least developed countries further receive special and preferential treatment for a wider coverage of products. The purpose of this program that has been established in the 1970s was to promote economic growth and development by stimulating least developed countries' exports. ${ }^{1}$

In the meantime Rose's conclusions have been challenged in a number of papers. Tomz, Goldstein and Rivers (2005) criticize the use of an OLS estimator, as it is a standard result in the econometric literature that the existence of individual specific effects causes OLS estimation to be biased and inconsistent. Instead, specific panel estimators such as fixed effects (FE) or random effects (RE) should be used. ${ }^{2}$ They also point out that

\footnotetext{
${ }^{1}$ See http://www.unctad.org.

${ }^{2}$ E. g. see Baltagi, ed (2001) or Greene, ed (2002).
} 
Rose's definition of WTO membership as de jure accession to the WTO can differ from de facto accession. Concerning WTO membership Tomz et al. (2005) point out three situations in which non-members have been de facto treated as WTO members, namely (i) so-called territories in responsibility, (ii) colonies that gained independence, and (iii) designated applicant countries. Taking into account FE estimation and controlling for de facto GATT/WTO membership Tomz et al. (2005) find that the WTO has a substantial effect on aggregated bilateral trade increasing the trade volume by about $72 \%$ if both trading partners are WTO members and $31 \%$ if only one country participates in the WTO. In comparison, the Generalized System of Preferences is less effective and increases trade by $21 \%$. Tomz et al. (2005) do not address another evident shortcoming of Rose's (2004) analysis, namely the use of aggregated bilateral trade data.

According to the original form of the gravity model bilateral trade as the regressand should be used in a disaggregate manner to account for the direction of trade in order to capture asymmetric effects of trade agreements on imports and exports. ${ }^{3}$ This point is of particular importance when examining the issue of trade redirection that might appear in case of only one trading partner participating in the GATT/WTO. In addition, disaggregated trade flows are necessary to appropriately account for asymmetric trade agreements as the Generalized System of Preferences (GSP). Subramanian and Wei (2003) deal with this problem and generalize Rose (2004) by using export and import volumes instead of aggregate trade volumes between the trading partners. They find that in general GATT/WTO has promoted bilateral trade with a particularly large effect on imports of industrialized countries but relatively small effects on the imports of developing countries. Bilateral trade is increased by $86 \%$ (4\%) if both the industrialized (developing) importer and its partner are GATT/WTO members and by $41 \%$ (12\%) if only the industrialized (developing) importer participates. If importers grant GSP, trade is enhanced by $49 \%$. A problem with the estimates is that they use panel data from 1950 through 2000 in 5-year intervals only and thus do not utilize the additional information implied by annual data.

Although Tomz et al. (2005) and Subramanian and Wei (2003) improve Rose's approach they do so in restricted ways. While Tomz et al. (2005) apply a FE estimator and the more appropriate de facto membership they continue to use aggregate trade instead of disag-

\footnotetext{
${ }^{3}$ See e. g. Anderson and van Wincoop (2003) or Bergstrand (1985).
} 
gregate export and import flows. In doing so they can neither account for the asymmetric effects of bilateral trade agreements nor for the role of asymmetric trade agreements. In contrast, Subramanian and Wei (2003) differentiate exports and imports but they do not use annual data and account for de jure WTO members only. As a consequence their estimates are biased and they underestimate the role of (de facto) WTO membership. To account for possible interactions between these different features we generalize these approaches, i. e. we use annual data from 1962 to 1999 for disaggregated export and import flows, account for de facto WTO membership, and apply the FE estimator. Since the WTO aims to liberalize a country's imports, we specify the case of only one country being a GATT/WTO member as a situation in which the insider is an importing country whereas the exporter is not. The same applies to the Generalized System of Preferences where we consider the imports of GSP granting countries only. ${ }^{4}$

Our empirical results indicate that the WTO does matter! According to our point estimates bilateral trade increases by $38 \%$ if both the importing and exporting country are WTO members and $22 \%$ if only the importing country is a member. The latter result suggests that on balance trade is not redirected as a country accedes the WTO, but rather that WTO members have more liberal trade regimes. Concerning the impact of the WTO on bilateral trade our results generally support the findings of Tomz et al. (2005) and Subramanian and Wei (2003). But they also reveal that trade flows between countries are affected asymmetrically depending on their income level as far as WTO membership of both countries is concerned. In addition, we find robust evidence that other multilateral institutions like regional trade agreements and currency unions foster bilateral trade as well.

Contrary to Tomz et al. (2005) and Subramanian and Wei (2003), our analysis indicates that the Generalized System of Preferences is negatively associated with the imports of the preference granting countries. This might be due to the political economy of GSP schemes which are typically granted for products that are relatively unimportant for GSP granting countries. As soon as these products become economically important, GSP schemes are often limited by quotas, product exclusions and other restrictive measures.

\footnotetext{
${ }^{4}$ Other papers do not differentiate between the exports from developing countries to their GSP granting countries and the export flows in the opposite direction. Instead, they define the GSP scheme by 1 if just a relationship between GSP granting countries and their partners exists.
} 
While previous work has focused on product level, we find evidence for this effect on the macro level. Comparing our analysis with previous studies we find that this result hinges on including very small countries in the data set. Hence, we conclude that the finding of a positive WTO effect is a robust result that also holds for other multilateral institutions like regional trade agreements and currency unions. In contrast, the impact of the GSP is likely to be negative.

The paper proceeds as follows. Section 2 presents the main features of our approach, in particular the gravity equation and the estimation method. Section 3 presents our empirical results and relates them to the literature. Section 4 concludes.

\section{The Model}

Following Rose (2004) we estimate a standard gravity model of bilateral trade. The basic model explains trade volume by the distance of the trading partners and their aggregate income. Rose (2004) extends the standard model by adding independent variables encompassing cultural, geographic, and historical factors. The strategy is to control for other natural sources of trade. One of these natural sources are trade agreements like GATT/WTO.

In a first step we discuss the broad version of the gravity equation as used in Rose (2004) to provide an overview and a better understanding of the research strategy.

$\log$ bilateral trade $=\alpha+\beta_{1}$ both partners inside the $\mathrm{WTO}+\beta_{2}$ one inside

$$
\begin{aligned}
& +\beta_{3} \text { GSP }+\gamma_{1} \text { log real GDP }+\gamma_{2} \text { log real GDP per capita } \\
& +\gamma_{3} \text { regional trade agreement }+\gamma_{4} \text { currency union } \\
& +\gamma_{5} \text { currently colonized }+\gamma_{6} \text { log distance } \\
& +\gamma_{7} \text { common language }+\gamma_{8} \text { common border } \\
& +\gamma_{9} \text { common colonizer }+\gamma_{10} \text { ever colony } \\
& +\gamma_{11} \text { common country }+\gamma_{12} \text { landlocked }+\gamma_{13} \text { island } \\
& +\gamma_{14} \text { log common area }+\sum_{t}^{T} \Phi_{t} D_{t}+\varepsilon_{i j t}
\end{aligned}
$$

where $i$ and $j$ denote trading partners and $t$ denotes time. 
While distance and real GDP follow directly from the gravity model the next three control variables account for the influence of trade policy. In particular we distinguish the following situations:

- both partners inside the WTO is a binary dummy variable that is defined as 1 if both trading partners are WTO members. If WTO membership stimulates bilateral trade, the coefficient should be positive.

- one inside is a binary dummy variable defined as 1 if only the importing country is WTO member. There are at least two hypotheses concerning this variable. The parameter could capture trade diversion due to one country being WTO member while the other being outside WTO. If trade diversion is relevant, the coefficient should be negative. Alternatively, WTO membership could provide a public good by liberalizing trade in general vis-à-vis not only other WTO members but also non-members. If this view is correct, the coefficient should have a positive sign.

- GSP accounts for membership in the Generalized System of Preferences and is defined by 1 if the importing country grants the GSP scheme to the exporting country, 0 otherwise. Concerning this parameter, there also exist at least two hypotheses. With respect to the original purpose of the GSP, the coefficient should be positive if the GSP raises the imports of the GSP granting country. In contrast, this coefficient should be negative if we find GSP granting countries to behave opportunistically, i. e. they grant GSP schemes as long as the selected products are not important for their imports, but as soon as they get relevant, the industrialized countries impose quotas, product exclusions and other restrictive measures.

The remaining variables control for geographic, economic and cultural similarities and dissimilarities of the trading partners which could foster or impede bilateral trade. All of these standard variables are described in the appendix. Obviously, when applying FE estimation the time-invariant variables drop out of the analysis.

Following Tomz et al. (2005) we base WTO membership on de facto rather than de jure accession. Disregarding informal WTO membership causes a systematic downward bias in the estimated effect of the WTO, especially the role of Most Favored Nations (MFN) 
which is granted to informal WTO members. ${ }^{5}$ Several countries were informally treated as GATT members, although not being endowed with all the rights and obligations of a formal GATT member. Tomz et al. (2005) pointed out three situations in which formal non-members were actually treated as members. Firstly, some contracting parties like Belgium, The Netherlands, Portugal, Spain, and United States applied the GATT to all of their colonies under the so-called rule of territories in responsibility, while others like Denmark, France, and United Kingdom did so only partly. ${ }^{6}$ Secondly, as colonies became independent they could decide whether to join the GATT, a process which could last several years. ${ }^{7}$ During this time these countries were de facto GATT members as they received the Most Favored Nation (MFN) status, but were excluded from several GATT privileges such as voting and the resolution of disputes. ${ }^{8}$ Thirdly, the same treatment was adopted for countries with application status. Several WTO members granted MFN treatment to selected applicants while negotiations for full accession were still taking place. Thus, applicants did not receive the special treatment generally. ${ }^{9}$

In the gravity model the direction of trade flows matters. ${ }^{10}$ We therefore use export and import data instead of aggregated trade. ${ }^{11}$ Only in this way it is possible to adequately control for the asymmetric effects of trade agreements, e. g. if only one of the two trading partners is WTO member or if trade is liberalized unilaterally as in GSP. Hence, we define the situation of only one GATT/WTO member as only the importing country participating in the GATT/WTO. Since the Generalized System of Preferences mainly affects the exports of developing countries to their partners granting the GSP schemes, we account for the imports of the granting countries from their GSP partners. ${ }^{12}$

\footnotetext{
${ }^{5}$ See Tomz et al. (2005).

${ }^{6}$ See GATT 1947, Article XXVI, Paragraph 5 (a). For example, Antigua and Barbuda or Belize do not appear explicitly as WTO members. Both Nations acceded WTO de jure in 1981 but they actually became WTO members as colonies since the United Kingdom joined the WTO in 1948.

${ }^{7}$ See GATT 1947, Article XXVI, Paragraph 5 (c). For example, Antigua and Barbuda got full autonomy from the UK in 1981 and joined the GATT six years later in 1987. Some countries were even faster like Belize which got independent in 1981 and entered the Agreement only two years later. Other countries like Ghana gained independence and GATT/WTO membership in the same year.

${ }^{8}$ Since the foundation of the WTO transitional periods are not granted any more.

${ }^{9}$ This was the case e. g. for Switzerland that applied to GATT in 1958 and eventually acceded in 1966.

${ }^{10}$ See e. g. Anderson and van Wincoop (2003) or Bergstrand (1985).

${ }^{11}$ Following Subramanian and Wei (2003) we split up the regressand, aggregate bilateral trade, into exports and imports, i. e. the data set accounts for the imports from country $i$ to $j$ and for the imports from country $j$ to $i$.

${ }^{12}$ The export flows of the developing countries in a GSP relationship are identical to the imports of the
} 
Our sample covers 145 countries during the period 1962 to 1999 with annual data. The export/import data are from Feenstra, Lipsey, Deng, Ma and Mo (2004) while the other variables originate from Rose (2004). To account for de facto WTO membership we modified the Rose data according to Tomz et al. (2005).

As proposed by Greene (2002) and Baltagi (2001) we use panel estimators to account for individual specific effects to avoid biased estimation results. While Cheng and Wall (2005) and Wall (1999) propose FE and RE models for the estimation of gravity models we follow Tomz et al. (2005) using a FE estimator for our regressions which is also suggested by our post estimation tests. ${ }^{13}$

\section{Estimation results}

In the following we present our empirical results (indicated as HW) and relate them to the estimations of Rose (2004) (RO), Tomz et al. (2005) (TGR), Subramanian and Wei (2003) (SW). By doing so we want to analyze which of the different features - FE estimation, membership definition, sample size, length of time period, disaggregated bilateral trade flows - is responsible for differences between the empirical results and how robust the results found in the literature are. Firstly, we apply the FE estimator to the original data set of Rose (2004) (indicated as RO-FE) in order to link the analyses of RO and TGR which differ in the choice of the estimator and the de facto WTO membership. ${ }^{14}$ Secondly, we investigate the gap between TGR and SW. As the differences between these two studies are more complex, we pursue this issue from two sides. Our regression (HW) differs from TGR insofar as we use disaggregated bilateral trade data. This feature shortens the observation period from 1949-99 to 1962-99 and reduces the country sample from 178 to

GSP granting countries. We use the imports of the latter so that we are consistent with the definition of only the importing country participating in the GATT/WTO.

${ }^{13}$ The correlation coefficient of $\operatorname{corr}\left(\mathrm{u}_{i}, \mathrm{Xb}\right)=-0.2796$ indicates endogenity between the independent variables and the individual-specific error terms with which a FE estimator can cope, instead of the RE estimator. The Hausman test gives information about the consistency and efficiency of the estimators. The $\mathrm{FE}$ is consistent under the null-hypothesis and the alternative whereas the RE is consistent and efficient under the null-hypothesis but inconsistent under the alternative. The null-hypothesis can be rejected with $\operatorname{chi}^{2}(45)=1437.70$ which means that the FE estimator is to be favored due to its consistency.

${ }^{14}$ We are able to dublicate the results of Rose with our replication exactly. We are also able to reconstruct the estimates of Tomz et al. (2005) almost exactly. All coefficients differ only by a maximum of $3 / 100$, while all standard errors are smaller. A severe difference appears in the goodness-of-fit of the model. Our $\mathrm{R}^{2}$ is $51.9 \%$ while Tomz et al. (2005) report $85.3 \%$. 
145 countries. Our regression differs from SW as we use annual data which also shortens the number of countries in the sample. Additionally, we consider only the importers are GATT/WTO members and we account only the importers that grant the GSP schemes.

\begin{tabular}{|c|c|c|c|c|c|}
\hline & RO & RO-FE & TGR & SW & HW \\
\hline Both participate in GATT/WTO & $\begin{array}{l}-0,04 \\
(0,05)\end{array}$ & $\begin{array}{c}0,13 \\
(0,02)^{\star \star \star}\end{array}$ & $\begin{array}{c}0,53 \\
(0,03)^{\star \star *}\end{array}$ & \begin{tabular}{r|l}
0,62 & $0,04^{1}$ \\
$(0,05)^{\star * \star} \mid$ & $(0,02)^{* \star}$
\end{tabular} & $\begin{array}{c}0,32 \\
(0,02)^{\star \star \star}\end{array}$ \\
\hline One participates in GATT/WTO & $\begin{array}{l}-0,06 \\
(0,05)\end{array}$ & $\begin{array}{c}0,06 \\
(0,02)^{\star * \star}\end{array}$ & $\begin{array}{c}0,24 \\
(0,02)^{\star * *}\end{array}$ & \begin{tabular}{r|l}
0,34 & $0,11^{2}$ \\
$(0,06)^{* \star *}$ & $(0,04)^{* \star *}$
\end{tabular} & $\begin{array}{c}0,20 \\
(0,02)^{* \star *}\end{array}$ \\
\hline GSP & $\begin{array}{c}0,86 \\
(0,03)^{\star \star \star}\end{array}$ & $\begin{array}{c}0,18 \\
(0,01)^{\star \star \star}\end{array}$ & $\begin{array}{c}0,19 \\
(0,01)^{\star \star *}\end{array}$ & $\begin{array}{c}0,40 \\
(0,06)^{* * *}\end{array}$ & $\begin{array}{l}-0,17 \\
(0,01)^{\star * *}\end{array}$ \\
\hline Log product real GDP & $\begin{array}{c}0,92 \\
(0,01)^{\star * *}\end{array}$ & $\begin{array}{c}0,44 \\
(0,02)^{\star \star \star}\end{array}$ & $\begin{array}{c}0,44 \\
(0,02)^{\star \star \star *}\end{array}$ & \begin{tabular}{c|c}
0,54 & $0,11^{3}$ \\
$(0,05)^{\star \star *}$ & $(0,06)^{* \star}$
\end{tabular} & $\begin{array}{c}1,09 \\
(0,02)^{\star \star *}\end{array}$ \\
\hline Log product real GDP per capita & $\begin{array}{c}0,32 \\
(0,01)^{\star \star *}\end{array}$ & $\begin{array}{c}0,24 \\
(0,02)^{\star \star \star}\end{array}$ & $\begin{array}{c}0,23 \\
(0,02)^{\star \star \star}\end{array}$ & $\begin{array}{l}-0,08 \mid 0,37^{4} \\
(0,05) \mid(0,05)^{\star \star \star}\end{array}$ & $\begin{array}{l}-0,42 \\
(0,02)^{\star \star \star}\end{array}$ \\
\hline Regional trade agreement & $\begin{array}{c}1,20 \\
(0,11)^{\star \star \star}\end{array}$ & $\begin{array}{c}0,76 \\
(0,04)^{\star \star *}\end{array}$ & $\begin{array}{c}0,78 \\
(0,04)^{\star \star *}\end{array}$ & $\begin{array}{c}0,99 \\
(0,05)^{\star \star \star}\end{array}$ & $\begin{array}{c}0,46 \\
(0,03)^{\star \star \star}\end{array}$ \\
\hline Currency union & $\begin{array}{c}1,12 \\
(0,12)^{\star \star \star}\end{array}$ & $\begin{array}{c}0,63 \\
(0,05)^{\star \star *}\end{array}$ & $\begin{array}{c}0,61 \\
(0,05)^{\star \star *}\end{array}$ & $\begin{array}{c}0,73 \\
(0,08)^{\star \star \star}\end{array}$ & $\begin{array}{c}0,73 \\
(0,06)^{\star * *}\end{array}$ \\
\hline Currently colonized & $\begin{array}{c}1,08 \\
(0,23)^{\star \star \star}\end{array}$ & $\begin{array}{c}0,30 \\
(0,09)^{\star \star *}\end{array}$ & $\begin{array}{c}0,27 \\
(0,09)^{\star \star *}\end{array}$ & $\begin{array}{c}0,94 \\
(0,14)^{\star \star *}\end{array}$ & $\begin{array}{c}0,35 \\
(0,09)^{\star * *}\end{array}$ \\
\hline Log distance & $\begin{array}{l}-1,12 \\
(0,02)^{\star \star \star}\end{array}$ & & & $\begin{array}{l}-0,92 \\
(0,02)^{\star \star \star}\end{array}$ & \\
\hline Common language & $\begin{array}{c}0,31 \\
(0,04)^{\star \star \star}\end{array}$ & & & $\begin{array}{c}0,13 \\
(0,03)^{\star \star *}\end{array}$ & \\
\hline Common border & $\begin{array}{c}0,53 \\
(0,11)^{\star * \star}\end{array}$ & & & $\begin{array}{l}0,03 \\
(0,06)\end{array}$ & \\
\hline Common colonizer & $\begin{array}{c}0,58 \\
(0,07)^{\star \star \star}\end{array}$ & & & $\begin{array}{c}0,53 \\
(0,05)^{\star * *}\end{array}$ & \\
\hline Ever in a colonial relationship & $\begin{array}{c}1,16 \\
(0,12)^{\star \star \star}\end{array}$ & & & $\begin{array}{c}1,16 \\
(0,07)^{\star \star \star}\end{array}$ & \\
\hline Common country & $\begin{array}{l}-0,02 \\
(1,08)\end{array}$ & & & $\begin{array}{l}-0,70 \\
(0,53)\end{array}$ & \\
\hline Landlocked & $\begin{array}{l}-0,27 \\
(0,03)^{\star \star \star}\end{array}$ & & & & \\
\hline Island & $\begin{array}{l}0,04 \\
(0,04)\end{array}$ & & & & \\
\hline Log product land area & $\begin{array}{c}-0,10 \\
(0,01)^{\circ 00}\end{array}$ & & & & \\
\hline R-squared & $64,8 \%$ & $52,4 \%$ & $52,0 \%$ & $71,5 \%$ & $37,7 \%$ \\
\hline Observations & 234.597 & 234.597 & 234.597 & 55.831 & 271.169 \\
\hline Groups & 12.150 & 12.150 & 12.150 & & 12.614 \\
\hline Countries & 178 & 178 & 178 & 177 & 145 \\
\hline
\end{tabular}

Table 1: Core regressions.

For all estimations the parameter values of the control variables are generally in line with our expectations as all control variables with the exception of per capita income affect 
trade positively. An increase in common real GDP obviously promotes trade (see table 1). Currency unions enhance trade as do regional free trade areas and current colonial relationships. A comparison across all five regressions reveals that the parameter values differ somewhat, but the substantially positive impact on bilateral trade is common to all estimations. The common real GDP per capita has a negative sign in our regressions. Bergstrand (1989) shows that the expectation of a positive sign strongly depends on the assumptions made on the traded goods and that the expected coefficient sign would change as soon as at least one of these assumptions fails. Next, we will discuss the main differences between the various regressions.

According to the original RO estimates, GATT/WTO membership does not have a significant effect on bilateral trade, neither if both trading partners are members nor if only one country is an insider. In contrast, he finds a strong effect of GSP on bilateral trade. If one country grants the Generalized System of Preferences to his partner, bilateral trade more than doubles $(136 \%=\exp (0.86)-1)$.

In contrast, TGR identify a positive correlation between WTO membership and bilateral trade which is significant if both traders are WTO members as well as if only one is inside the club. In quantitative terms, bilateral trade is about $70 \%$ higher if both countries participate in the WTO and around $27 \%$ if only one of them is WTO member. In comparison to RO both membership coefficients are higher with greater p-values, whereas all other coefficients are smaller. Especially the effect of GSP on bilateral trade declines to a quarter of the value estimated by Rose.

To see whether these conflicting results concerning WTO membership are due to the difference in the estimator or the WTO membership definition, we apply a FE estimator instead of OLS (indicated by RO-FE) to the original data set of Rose (2004). We find that the coefficients for all variables are very similar to TGR. In particular, the negative correlation of the GATT/WTO membership on bilateral trade found by Rose turns positive and gains significance. ${ }^{15}$ Tomz et al.'s (2005) adjustment of WTO accession dates

\footnotetext{
${ }^{15} \mathrm{As}$ mentioned above, the use of OLS is not appropriate for the current data set, instead, panel estimators like FE or RE are. We performed the Hausman test on this regression which suggests the FE estimator to be used.
} 
strengthens the positive impact of GATT/WTO membership on bilateral trade. This indicates that the TGR results are primarily driven by the estimation methodology and amplified by the membership adjustment.

SW use a different data set as they account for the direction of the bilateral trade flows. They find that GSP promotes trade by $49 \%$, a larger effect than found by RO-FE or TGR. Concerning the effect of WTO membership, they differentiate between industrialized and developing countries. The left hand side of column SW (table 1) displays the estimation results for the imports of industrialized countries, while the right hand side of column SW gives the estimates for developing countries. The results show that WTO membership generally affects bilateral trade in a positive way, but more so for industrialized importers than developing importers.

In order to simultaneously account for FE estimation, disaggregated trade flows, de facto WTO membership, and annual data, we adopted the new definition of WTO membership from Tomz et al. (2005) as well as the separation of aggregate bilateral trade data into export and import flows according to Subramanian and Wei (2003). With respect to WTO membership our own results (HW) are in line with TGR and SW. We find a strong trade enhancing effect of WTO. If both countries are WTO members, trade is increased by roughly one third. If only the importing country accedes WTO, trade is enhanced by a quarter. As was discussed above, the variable one inside can be interpreted as capturing either trade diversion effects or public goods effects of WTO membership. The significantly positive coefficient indicates that the WTO membership has positive external effects in the sense that countries that join WTO have in general a more liberal trade regime not only vis-à-vis other WTO members but also vis-à-vis outsiders. Apparently, a possible trade diversion effect of WTO is more than compensated. The trade enhancing effect is even higher if both trading partners participate in the WTO. There also exists strong statistical evidence that membership in a regional trade agreement like the European Union or in a currency union like the euro area increases bilateral trade significantly, which is robust across all regressions.

Concerning GSP, our empirical results differ distinctly from previous studies. We find a significantly negative effect of the Generalized System of Preferences of around $-16 \%$ on bilateral trade while all other regressions report a substantially positive impact. In- 
stead of enhancing trade, the GSP seems to inhibit bilateral trade. This might be due to the political economy of GSP schemes which are typically granted for products that are relatively unimportant for GSP granting countries. As soon as these products become economically important, GSP schemes are often limited by quotas, product exclusions and other restrictive measures. ${ }^{16}$ While previous work has focused on product level, we find evidence for this effect on the macro level.

Summing up so far, there exists robust evidence in TGR, SW and HW that WTO membership fosters bilateral trade. Referring to the control variables, the results show the same tendency across all regressions. Especially membership in other multilateral institutions, namely regional trade agreements or currency unions, exerts substantial positive implications on bilateral trade across countries. Although there are many similarities across the estimations there is one obvious difference, namely the negative relation of the Generalized System of Preferences and bilateral trade. While the other regressions identify positive relationships between the GSP and bilateral trade, we detect a significantly negative association which we examine in more detail below.

\section{Is the difference in the GSP effect due to the shorter observation period or the}

smaller country sample? As a next step we look into possible causes for the difference in the estimated GSP effect. As a starting point we take the regression of TGR which is based on the data set of Rose (2004). Our data set which is based on Feenstra et al. (2004) differs from the Rose (2004) data in that it differentiates between exports and imports, while Rose's data cover aggregate trade only. This comes at a price as our data set is shorter (1949 - 1999 versus 1962 - 1999) and as it lacks a number of very small countries with less than one million inhabitants (178 countries versus 145 countries). ${ }^{17}$ Hence, we re-estimate TGR with a shorter time period, namely from 1962-99, and afterwards we additionally account for the smaller country sample (SCS) (table 2).

In TGR (62-99), we re-estimate TGR adapting the observation period to 1962-1999. Although approximately 20,000 observations are dropped, this does not seem to have a

\footnotetext{
${ }^{16}$ For theoretical considerations see Langhammer and Sapir (1987) or Manchin (2005). Hoekman and Özden (2005) provide for a sound review of empirircal literature.

${ }^{17} \mathrm{~A}$ comparison of TGR and SW indicates that the results do not depend on the application of annual versus disaggregated trade data, but rather on the length of the observation period and/or the size of the country sample.
} 
significant effect on the results. Both coefficients concerning the WTO membership decrease somewhat, whereas the GSP effect remains roughly constant.

\begin{tabular}{|c|c|c|c|}
\hline & TGR & TGR (62-99) & TGR (SCS) \\
\hline Both participate in GATT/WTO & $\begin{array}{c}0,53 \\
(0,03)^{\star \star \star}\end{array}$ & $\begin{array}{c}0,48 \\
(0,03)^{\star \star \star}\end{array}$ & $\begin{array}{c}0,43 \\
(0,03)^{\star \star \star}\end{array}$ \\
\hline One participates in GATT/WTO & $\begin{array}{c}0,24 \\
(0,02)^{\star \star \star}\end{array}$ & $\begin{array}{c}0,17 \\
(0,03)^{\star \star \star}\end{array}$ & $\begin{array}{c}0,19 \\
(0,03)^{\star \star \star}\end{array}$ \\
\hline GSP & $\begin{array}{c}0,19 \\
(0,01)^{\star \star \star}\end{array}$ & $\begin{array}{c}0,17 \\
(0,01)^{\star \star \star}\end{array}$ & $\begin{array}{c}-0,03 \\
(0,01)^{\star \star}\end{array}$ \\
\hline Log product real GDP & $\begin{array}{c}0,44 \\
(0,02)^{\star \star \star}\end{array}$ & $\begin{array}{c}0,48 \\
(0,02)^{\star \star \star}\end{array}$ & $\begin{array}{c}0,75 \\
(0,02)^{\star \star \star}\end{array}$ \\
\hline Log product real GDP per capita & $\begin{array}{c}0,23 \\
(0,02)^{\star \star \star}\end{array}$ & $\begin{array}{c}0,13 \\
(0,02)^{\star \star \star}\end{array}$ & $\begin{array}{c}-0,08 \\
(0,02)^{\star \star \star}\end{array}$ \\
\hline Regional trade agreement & $\begin{array}{c}0,78 \\
(0,04)^{\star \star \star}\end{array}$ & $\begin{array}{c}0,51 \\
(0,04)^{\star \star \star}\end{array}$ & $\begin{array}{c}0,51 \\
(0,03)^{\star \star \star}\end{array}$ \\
\hline Currency union & $\begin{array}{c}0,61 \\
(0,05)^{\star \star \star}\end{array}$ & $\begin{array}{c}0,59 \\
(0,06)^{\star \star \star}\end{array}$ & $\begin{array}{c}0,62 \\
(0,06)^{\star \star \star}\end{array}$ \\
\hline Currently colonized & $\begin{array}{c}0,27 \\
(0,09)^{\star \star \star}\end{array}$ & $\begin{array}{c}0,13 \\
(0,11) \\
\end{array}$ & $\begin{array}{c}0,26 \\
(0,09)^{\star * \star}\end{array}$ \\
\hline R-squared & $52,0 \%$ & $51,5 \%$ & $50,3 \%$ \\
\hline Observations & 234.597 & 215.354 & 132.519 \\
\hline Groups & 12.150 & 12.147 & 6.214 \\
\hline Countries & 178 & 177 & 145 \\
\hline
\end{tabular}

Table 2: Modification of the TGR approach [shorter time period (TGR 62-99) and a smaller country sample (TGR SCS)].

In TGR (SCS) we additionally account for the effect of the smaller country sample, again using data from 1962-1999. ${ }^{18}$ The effects of WTO membership are similar, but the impact of the GSP turns significantly negative although the coefficient is relatively small (-0.03). Thus, the positive effect of GSP on trade found by several authors is not robust and seems to be due to the specific role of small countries of less than one million inhabitants.

We therefore conclude that GSP typically seems to have a negative effect on trade, with the exception of very small countries and territories. In contrast, shortening the data set by leaving out the 1950s does not change the empirical results.

Does the GSP effect depend on the level of development? Table 3 takes a look at trade between countries with different development levels. Following the definition of

\footnotetext{
${ }^{18}$ Since we use disaggregated bilateral trade data for the HW regressions, observations and trade relations drop out which can be retraced in the appendix of the paper.
} 
Rose (2004) we differentiate three groups of countries, low income, middle income and high income countries.

\begin{tabular}{|c|c|c|c|c|c|c|c|c|c|c|}
\hline & \multirow[b]{2}{*}{ HW } & \multicolumn{9}{|c|}{ HW } \\
\hline & & $\begin{array}{l}\text { high im/ } \\
\text { high ex }\end{array}$ & $\begin{array}{l}\text { middle im/ } \\
\text { middle ex }\end{array}$ & $\begin{array}{l}\text { low im/ } \\
\text { low ex }\end{array}$ & $\begin{array}{l}\text { high im/ } \\
\text { middle ex }\end{array}$ & $\begin{array}{l}\text { middle im/ } \\
\text { high ex }\end{array}$ & $\begin{array}{l}\text { high im/ } \\
\text { low ex }\end{array}$ & $\begin{array}{l}\text { low im/ } \\
\text { high ex }\end{array}$ & $\begin{array}{l}\text { middle im/ } \\
\text { low ex }\end{array}$ & $\begin{array}{c}\text { low im/ } \\
\text { middle ex }\end{array}$ \\
\hline Both participate in GATT/WTO & $\begin{array}{c}0,32 \\
(0,02)^{* * *}\end{array}$ & $\begin{array}{c}0,42 \\
(0,04)^{\star \star \star}\end{array}$ & $\begin{array}{c}0,16 \\
(0,04)^{* * *}\end{array}$ & $\begin{array}{c}0,63 \\
(0,32)^{\star *}\end{array}$ & $\begin{array}{c}0,10 \\
(0,05)^{* *}\end{array}$ & $\begin{array}{l}0,03 \\
(0,02)\end{array}$ & $\begin{array}{l}0,00 \\
(0,07)\end{array}$ & $\begin{array}{c}0,18 \\
(0,08)^{* *}\end{array}$ & $\begin{array}{c}0,36 \\
(0,06)^{* \star *}\end{array}$ & $\begin{array}{c}0,27 \\
(0,16)^{*}\end{array}$ \\
\hline Importer in, exporter out & $\begin{array}{c}0,20 \\
(0,02)^{* * *}\end{array}$ & $\begin{array}{c}0,67 \\
(0,05)^{* * \star}\end{array}$ & $\begin{array}{c}0,15 \\
(0,04)^{* * *}\end{array}$ & $\begin{array}{l}0,26 \\
(0,40)\end{array}$ & $\begin{array}{l}-0,04 \\
(0,05)\end{array}$ & $\begin{array}{c}0,15 \\
(0,06)^{* * \star}\end{array}$ & $\begin{array}{l}-0,08 \\
(0,10)\end{array}$ & $\begin{array}{c}1,10 \\
(0,11)^{\star \star *}\end{array}$ & $\begin{array}{c}0,87 \\
(0,11)^{\star * *}\end{array}$ & $\begin{array}{l}0,17 \\
(0,17)\end{array}$ \\
\hline GSP (importer) & $\begin{array}{l}-0,17 \\
(0,01)^{* * \star}\end{array}$ & (dropped) & $\begin{array}{c}-0,86 \\
(0,10)^{* \star *}\end{array}$ & (dropped) & $\begin{array}{c}-0,09 \\
(0,03)^{\star \star \star}\end{array}$ & (dropped) & $\begin{array}{l}-0,01 \\
(0,03)\end{array}$ & (dropped) & $\begin{array}{c}-0,88 \\
(0,13)^{* \star \star}\end{array}$ & (dropped) \\
\hline Log product real GDP per capita & $\begin{array}{l}-0,42 \\
(0,02)^{* * *}\end{array}$ & $\begin{array}{c}0,25 \\
(0,03)^{* * *}\end{array}$ & $\begin{array}{c}-0,49 \\
(0,06)^{* * *}\end{array}$ & $\begin{array}{l}-0,04 \\
(0,14)\end{array}$ & $\begin{array}{c}-0,41 \\
(0,04)^{\star \star \star}\end{array}$ & $\begin{array}{c}-0,46 \\
(0,04)^{* \star *}\end{array}$ & $\begin{array}{c}0,99 \\
(0,08)^{* * *}\end{array}$ & $\begin{array}{c}0,44 \\
(0,06)^{\star \star \star}\end{array}$ & $\begin{array}{c}-0,42 \\
(0,10)^{* \star \star}\end{array}$ & $\begin{array}{l}-0,05 \\
(0,11)\end{array}$ \\
\hline Regional trade agreement & $\begin{array}{c}0,46 \\
(0,03)^{* * *}\end{array}$ & $\begin{array}{c}0,40 \\
(0,03)^{* * \star}\end{array}$ & $\begin{array}{l}0,12 \\
(0,11)\end{array}$ & $\begin{array}{l}0,13 \\
(0,72)\end{array}$ & $\begin{array}{l}0,05 \\
(0,14)\end{array}$ & $\begin{array}{c}0,40 \\
(0,12)^{* \star *}\end{array}$ & $\begin{array}{c}1,61 \\
(0,43)^{* * *}\end{array}$ & $\begin{array}{l}0,16 \\
(0,36)\end{array}$ & $\begin{array}{l}-0,26 \\
(0,33)\end{array}$ & $\begin{array}{l}0,11 \\
(0,32)\end{array}$ \\
\hline Currency union & $\begin{array}{c}0,73 \\
(0,06)^{* * *}\end{array}$ & $\begin{array}{c}0,55 \\
(0,08)^{* \star \star}\end{array}$ & $\begin{array}{l}-0,04 \\
(0,30)\end{array}$ & $\begin{array}{c}0,75 \\
(0,14)^{\star * \star}\end{array}$ & $\begin{array}{c}0,83 \\
(0,17)^{\star * *}\end{array}$ & $\begin{array}{c}0,40 \\
(0,14)^{\star \star \star}\end{array}$ & $\begin{array}{c}1,89 \\
(0,19)^{* * *}\end{array}$ & $\begin{array}{c}1,20 \\
(0,16)^{* * *}\end{array}$ & $\begin{array}{l}-0,61 \\
(0,33)^{*}\end{array}$ & $\begin{array}{l}0,20 \\
(0,35)\end{array}$ \\
\hline
\end{tabular}

Table 3: HW (importer inside, GSP importer) by income.

Concerning WTO membership of both trading countries, our estimation indicates that WTO membership is generally favorable as seven out of nine coefficients are significantly positive and none of the remaining is significantly negative. Collective WTO membership increases imports of high income countries from middle income countries significantly by $11 \%$, whereas imports of middle income countries from high income countries are not affected by WTO accession.

By contrast, imports of high income countries from low income countries do not change significantly, whereas imports of low income countries from high income countries increase by $20 \%$. Generally, WTO membership of both partners enhances trade for countries of all income levels, but trade flows between high income countries and middle as well as low income countries are affected unequally. ${ }^{19}$

Referring to WTO membership of the importing country only, the average effect on trade flows is positive. A detailed analysis for the different income levels reveals that the WTO effect is either significantly positive or not significant at all. Although the results of WTO membership of one partner are mixed and one cannot ascertain any clear pattern, the

\footnotetext{
${ }^{19}$ Subramanian and Wei (2003) state that collective WTO membership is much more favorable for the imports of industrialized countries than for developing countries. With respect to our results, we share this opinion only partly.
} 
findings indicate that there occurs at least no trade diversion. Similar results hold for membership in other multilateral institutions. Regional trade agreements or currency unions are generally trade enhancing although sometimes the effect is not significant.

Concerning GSP, the average effect on imports is significantly negative in contrast to the findings of previous studies. Distinguishing different income levels reveals that this effect is relatively small if high income countries grant GSP to middle income countries and is even not significant if high income importers grant GSP to low income countries. While in contrast with RO, TGR and SW our findings are in line with the hypothesis of opportunistic behavior of industrialized countries, Langhammer and Sapir (1987) point out that the two components of GSP, the reduction of tariffs and the preferential treatment for suppliers, produce opposing effects, namely trade creation and trade diversion. In review of the empirical literature they report conflicting results as some studies found GSP net trade creation effects whereas others identified net trade diversion effects. Manchin (2005) points out several factors that restrict the effectiveness of GSP schemes. First, administrative and technical requirements often impose considerable burden on traders. Second, several GSP schemes are likely to be restricted to sectors, in which developing countries lack comparative advantage. Third, trade expansion effects by GSP schemes are often limited by quotas, product exclusions and other restrictive measures. In their survey of the empirical literature concerning the GSP effects, Hoekman and Özden (2005, p. 40) conclude that the GSP is likely not to contribute to the promotion of international trade of developing countries.

In contrast, the negative impact is relatively strong for medium income importers granting GSP to other middle income exporters or to low income exporters. It should be noted that the only middle income countries that offer GSP schemes are Bulgaria, Hungary, and Poland which during the 1980s faced severe socioeconomic problems affecting their imports negatively. Since these countries grant GSP schemes since the middle of the 1970s, this effect might be picked up by the GSP dummy although there need not to be a casual link. But still, the other GSP coefficients are either small or not significant, but never substantially positive.

Taken together, we conclude that GSP has negative or insignificant effects on trade. The average negative impact of GSP on bilateral trade in our regression is driven by its impact 
on the sub-samples of the trade relations of middle income importers and middle income exporters as well as low income exporters. ${ }^{20}$ Only in the special case of very small countries does GSP seem to have a positive effect.

\section{Conclusion}

In this paper we generalize the different approaches used in the literature to estimate the role of GATT/WTO and the Generalized System of Preferences for trade. We apply FE estimation on a disaggregated bilateral data set of the trade flows between 145 countries across 1962-99, and account for de facto WTO membership. In our analysis we find a significant positive effect of WTO membership on bilateral trade. It might not come as surprise that trade is higher if both trading partners are WTO members, but trade is generally also promoted if only the importer is a WTO insider. Concerning WTO membership of both trading partners, we find that the imports of high income countries from middle income countries as well as imports of high income countries from low income countries are affected differently as trade flows in the opposite direction. Referring to other multilateral institutions, we find robust evidence that membership in regional trade agreements or currency unions substantially increase bilateral trade flows as well.

Concerning the Generalized System of Preferences previous work found trade enhancing effects. In our sample we find that the GSP does not foster trade in general, rather the opposite. This might be due to the political economy of GSP schemes which are typically granted for products that are relatively unimportant for GSP granting countries. In case these imported products gain relevance, GSP schemes are often limited by quotas, product exclusions and other restrictive measures. Generally, one can observe this mechanism only on the product level, but we find evidence for this effect in a macroeconomic model. Comparing our analysis with previous studies we find that this result hinges on including very small countries in the data set. Hence, we conclude that the finding of a positive WTO effect is a robust result that also holds for other multilateral institutions like regional trade agreements and currency unions. In contrast, the impact of the GSP is likely to be negative.

\footnotetext{
${ }^{20}$ If we regress on bilateral imports without accounting for GSP schemes granted by Hungary, Poland and Romania, the average GSP coefficient is indeed around -0.09 .
} 


\section{References}

Anderson, James and Eric van Wincoop, "Gravity with gravitas: A solution to the border puzzle," American Economic Review, 2003, 93 (1), 170-92.

Baltagi, Badi H., ed., Econometric analysis of panel data, Chichester, England: John Wiley and Sons, Ltd, 2001.

Bergstrand, Jeffrey H., "The gravity equation in international trade: Some microeconomic foundations and empirical evidence," Review of Economics and Statistics, $1985,67,474-81$.

"The generalized gravity equation, monopolistic competition and the factorproportions theory in international trade," Review of Economics and Statistics, 1989, $71,143-53$.

Cheng, I.-H. and H.J. Wall, "Controlling for heterogeneity in gravity models of trade and integration," Federal Reserve Bank of St. Louis Review, 2005, 87 (1), 49-63.

Feenstra, Robert, Robert Lipsey, Haiyan Deng, Alyson Ma, and Hengyong Mo, "World Trade Flows: 1962-2000," NBER, Working Paper No. 11040, 2004.

Greene, William H., ed., Econometric Analysis, 5 ed., New Jersey: Pearson Education, 2002.

Hoekman, Bernard and Caglar Özden, "Trade preferences and differential treatment of developing countries," World Bank Policy Research Working Paper 3566, 2005.

Langhammer, Rolf and André Sapir, "Economic Impact of Generalized Tariff Preferences," Thames Essays, 1987, 49.

Manchin, Miriam, "Preference utilization and tariff reduction in European Union imports from Africa, Caribbean, and Pacific countries," World Bank Research Working Paper 3688, 2005.

Rose, Andrew K., "Do we really know that the WTO increases trade?," American Economic Review, 2004, 94 (1), 98-114. 
Subramanian, Arvind and Shang-Jin Wei, "The WTO Promotes Trade, Strongly but Unevenly," NBER Working Paper 10024, 2003.

Tomz, Michael, Judith Goldstein, and Douglas Rivers, "Membership has its Privileges: The Impace of GATT on Internatioinal Trade," 2005.

Wall, Howard, "Using the gravity model to estimate the costs of protection," Federal Reserve Bank of St. Louis, 1999.

\section{APPENDIX}

\section{APPENDIX A: Data adjustments}

To be able to combine the data sets of Rose and Feenstra, these are adjusted in the following way:

- Country correction

First, countries are adjusted, because both data sets contain partly different countries. In a first step, states have been eliminated that were not congruent in both data sets. Next, we have accounted for countries that experienced a reunification or a splitting during the period of interest. This reduced the number of nations to 145. A list of the adjusted nations can be seen in table below.

- Correction of trade relations

Despite the great number of coinciding trade relations, there are some differences. According to the country correction only these trading partners remain in the data set that exist simultaneously in both data sets. This adjustment leads to 16.924 trade relations.

- Adjustment of the longitudinal axis

The time axis has to be adjusted in order to sort out last gaps in the data set. Rose's data set reach from 1949 through 1999, while Feenstra's covers the period from 1962 through 2000. Thus, only the core interval of 1962 through 1999 is kept. 
- We drop trading pairs that have less than two observations which means 4,394 $\left(\approx 1.59 \%\right.$ ) observations are lost. ${ }^{21}$ Thus, the data set reduces to 271,169 observations.

\section{APPENDIX B: The variables}

- $\log$ Distance describes the log of the great circle distance of two trading countries. This geographic parameter implies the greater the distance the smaller the bilateral trade volume due to transportation costs; the coefficient is expected to be negative.

- log real GDP and log real GDP per capita represent the log of aggregate real GDP of both trading partners and the log of aggregate real GDP per capita, respectively. Higher income and income per capita imply a higher output volume and accordingly higher trade volumes. Both coefficients should be positive.

- regional trade agreement is a binary dummy variable defined 1 if both trading partners are members of the same regional trade agreement. This coefficient should be positive, because RTAs exercise positive effects on reciprocal trade of their members, e.g. EU countries.

border refers to geographical affiliation even more than regional because this binary dummy variable is defined 1 if both trading partners share a common border.

- currency union is a dummy variable defined 1 if both trading partners participate in the same currency union simultaneously.

- common language is a dummy variable defined 1 if both trading partners share the same language.

- common colonizer is defined 1 if both countries have ever been colonized after 1945 and had the same colonizer, otherwise 0 .

- currently colonized is a dummy variable and is defined 1 in a situation in which one of the trading partners has been the colonizer of the other at date $t$.

\footnotetext{
${ }^{21} \mathrm{~A}$ sensitivity analysis (not reported here) shows that there is no significant difference in the coefficients if one drops tradings pairs with only two or three observations.
} 
- ever colony is defined 1 if one of the two trading partners has been the colony of the other.

- common country is defined 1 if both trading partners have ever been part of a common nation.

- landlocked represents a discrete dummy variable defined 0,1 or 2 according to the number of the trading partners that have no access to waterways.

- island defines the analogous situation in the case of an island.

- log area represents the log of aggregate area of both trading countries. 


\section{APPENDIX C: Country list}

\begin{tabular}{|c|c|c|c|c|}
\hline $\begin{array}{l}\text { Country } \\
\text { (formal year of } \\
\text { accession) }\end{array}$ & $\begin{array}{l}\text { ence / } \\
\text { GATT } \\
\text { ship }\end{array}$ & $\begin{array}{l}\text { Country } \\
\text { (formal year of } \\
\text { accession) }\end{array}$ & $\begin{array}{c}\text { Independence / } \\
\text { informal GATT } \\
\text { membership }\end{array}$ & Colonizer \\
\hline Albania & & Equatorial Guinea & 1968 & Spain \\
\hline Algeria & 1962 France & Estonia (1999) & 1991 & UdSSR \\
\hline Angola (1994) & 1975 Portugal & Ethiopia & & \\
\hline Antigua and Barbuda (1987) & 1981 United Kingdom & Fiji (1993) & 1970 & United Kingdom \\
\hline Argentina $(1967)^{4)}$ & 1960 application & Finland (1950) & & \\
\hline Armenia & 1991 UdSSR & France (1948) & & \\
\hline Australia (1948) & & Gabon (1963) & 1960 & France \\
\hline Austria (1951) & & Gambia (1965) & 1965 & United Kingdom \\
\hline Azerbaijan & 1991 UdSSR & Georgia & 1991 & UdSSR \\
\hline Bahamas & 1973 United Kingdom & Germany (1951) & & \\
\hline Bahrain (1993) & 1971 United Kingdom & Ghana (1957) & 1957 & United Kingdom \\
\hline Bangladesh (1972) & 1971 Pakistan & Greece (1950) & & \\
\hline Barbados (1967) & 1966 United Kingdom & Grenada (1994) & 1974 & United Kingdom \\
\hline Belarus & 1991 UdSSR & Guatemala (1991) & & \\
\hline Belgium (1948) & & Guinea (1994) & 1958 & France \\
\hline Belize (1983) & 1981 United Kingdom & Guinea-Bissau (1994) & 1974 & Portugal \\
\hline Benin (1963) & 1960 France & Guyana (1966) & 1966 & United Kingdom \\
\hline Bermuda & still british colony & Haiti (1950) & & \\
\hline Bhutan & & Honduras (1994) & & \\
\hline Bolivia (1990) & & Hong Kong (1986) & & \\
\hline Botswana (1987) & 1966 United Kingdom & Hungary (1973) & & \\
\hline Brazil (1948) & & Iceland (1968) ${ }^{4)}$ & 1964 & application \\
\hline Bulgaria (1996) & & India (1948) & & \\
\hline Burkina Faso (1963) & 1960 France & Indonesia (1950) & 1949 & Netherlands \\
\hline Burma (Myanmar) (1948) & & Iran & & \\
\hline Burundi (1965) & 1962 Belgium & Iraq & & \\
\hline Cambodia & 1953 France & Ireland (1967) & & \\
\hline Cameroon (1963) & 1960 France & Israel (1962) ${ }^{4)}$ & 1959 & application \\
\hline Canada (1948) & & Italy (1950) & & \\
\hline Cape Verde & 1975 Portugal & Jamaica (1963) ${ }^{2)}$ & 1962 & United Kingdom \\
\hline Central African Rep. (1963) & 1960 France & Japan (1955) ${ }^{4)}$ & 1953 & application \\
\hline Chad (1963) & 1960 France & Jordan & & \\
\hline Chile (1949) & & Kazakhstan & 1991 & UdSSR \\
\hline China & & Kenya (1964) & 1963 & United Kingdom \\
\hline Colombia (1981) ${ }^{4)}$ & 1975 application & Kiribati & 1979 & United Kingdom \\
\hline Comoros & 1975 France & Korea, South (R) (1967) & & \\
\hline Congo, Dem. Re. of (Zaire) (1971) & 1960 Belgium & Kuwait (1963) & 1961 & United Kingdom \\
\hline Congo, Rep. (1963) & 1960 France & Kyrgyz Republic (1998) & 1991 & UdSSR \\
\hline Costa Rica (1990) & & Lao People's Dem. Rep. ${ }^{3)}$ & 1949 & France \\
\hline Côte D'Ivoire (Ivory Coast) (1963) & 1960 France & Latvia (1999) & 1991 & UdSSR \\
\hline Croatia & 1991 Yugoslavia & Lebanon & & \\
\hline Cyprus (1963) & 1960 United Kingdom & Lesotho (1988) & 1966 & United Kingdom \\
\hline Czeck Republic (1993) & & Liberia & & \\
\hline Denmark (1950) & & Libya & 1951 & Italy \\
\hline Djibouti (1994) & 1977 France & Lithuania & 1991 & UdSSR \\
\hline Dominica (1993) & 1978 United Kingdom & Luxembourg (1948) & & \\
\hline Dominican Rep. (1950) & & Macedonia & 1991 & Yugoslavia \\
\hline Ecuador (1996) & & Madagascar (1963) & 1960 & France \\
\hline Egypt (1970) ${ }^{4}$ & 1962 application & Malawi (1964) & 1964 & United Kingdom \\
\hline El Salvador (1991) & & Malaysia (1957) & 1957 & United Kingdom \\
\hline
\end{tabular}

Table 4: Complete country list with dates of de jure and de facto GATT/WTO 


\begin{tabular}{|c|c|c|c|c|}
\hline $\begin{array}{l}\text { Country } \\
\text { (formal year of } \\
\text { accession) }\end{array}$ & $\begin{array}{l}\text { Independence / } \\
\text { informal GATT Colonizer } \\
\text { membership }\end{array}$ & $\begin{array}{l}\text { Country } \\
\text { (formal year of } \\
\text { accession) }\end{array}$ & $\begin{array}{l}\text { nce / } \\
\text { ATT } \\
\text { hip }\end{array}$ & Colonizer \\
\hline Maldives (1983) & 1965 United Kingdom & Slovenia (1994) & 1991 & 1 Yugoslavia \\
\hline Malta (1964) & 1964 United Kingdom & Somalia & 1960 & 0 United Kingdom \\
\hline Mauritania (1963) & 1960 France & South Africa (1948) & & \\
\hline Mauritius (1970) & 1968 United Kingdom & Spain (1963) & & \\
\hline Mongolia (1997) & & St. Lucia (1993) & 1979 & 9 United Kingdom \\
\hline Morocco (1987) ${ }^{2)}$ & 1956 France & St. Vincent \& Gren. (1993) & 1979 & 9 United Kingdom \\
\hline Mozambique (1992) & 1975 Portugal & Sudan & 1956 & 6 United Kingdom \\
\hline Namibia (1992) & 1990 South Africa & Suriname (1978) & 1975 & 5 Netherlands \\
\hline Nepal & & Swaziland (1993) & 1968 & 8 United Kingdom \\
\hline Netherlands (1948) & & Sweden (1950) & & \\
\hline Oman & & Togo (1964) & 1960 & 0 France \\
\hline Pakistan (1948) & & Tonga & 1970 & 0 United Kingdom \\
\hline Panama (1997) & & Trinidad \& Tobago (1962) & 1962 & 2 United Kingdom \\
\hline Papua N. Guinea (1994) & 1975 Australia & Tunisia (1990) ${ }^{4)}$ & 1956 & 6 France (application 1959) \\
\hline Paraguay (1994) & & Turkey (1951) & & \\
\hline Peru (1951) & & Turkmenistan & 1991 & 1 UdSSR \\
\hline Philippines (1979) ${ }^{4)}$ & 1973 application & Uganda (1962) & 1962 & 2 United Kingdom \\
\hline Poland (1967) & & Ukraine & 1991 & 1 UdSSR \\
\hline Portugal (1962) & & United Arab Emirates (1994) & 1971 & 1 United Kingdom \\
\hline Qatar (1994) & 1971 United Kingdom & United Kingdom (1948) & & \\
\hline Reunion & still french colony & United States (1948) & & \\
\hline Romania (1971) & & Uruguay (1953) & & \\
\hline Slovak Republic (1993) & $\begin{array}{l}1993 \text { separation in Czech Rep. } \\
\text { and Slovenia }\end{array}$ & & & \\
\hline \multicolumn{5}{|c|}{ 1) Belgium, The Netherlands, Portugal, Spain, and the United States apply GATT for all of their colonies. } \\
\hline \multicolumn{5}{|c|}{ 2) France applied GATT for all overseas territories except Morocco; the UK adopted GATT for its entire empire except Jamaica. } \\
\hline \multicolumn{5}{|c|}{$\begin{array}{l}\text { 3) Countries that gained independence received a transitional period; that expired for Laos on 30th Oktober } 1958 \text { (see GATT protocols SR.12/11, L/761 } \\
\text { and SR.13/11). Since the foundation of the WTO transitional periods are not granted any more. }\end{array}$} \\
\hline \multicolumn{5}{|c|}{$\begin{array}{l}\text { 4) Japan applied in } 1953 \text { and was treated GATT-like since then. Similar arrangements were released for Switzerland (1958), Israel (1959), } \\
\text { Tunisia (1959), Yugoslavia (1959), Argentina (1960), Egypt (1962), Iceland (1964), Philippines (1973) and Columbia (1975). }\end{array}$} \\
\hline
\end{tabular}

Table 5: Complete country list (continued). 